\title{
Contingent Valuation of Lake Rawapening as a Source of Drinking Water
}

\section{Evi Irawan ${ }^{1}$}

${ }^{1}$ Balai Penelitian dan Pengembangan Teknologi Pengelolaan Daerah Aliran Sungai, Jl. A. Yani, Pabelan, P.O. Box 295, Surakarta, 57102; e-mail: evirawan17@gmail.com

\begin{abstract}
ABSTRAK
Tujuan penelitian ini adalah untuk mengestimasi nilai kesediaan membayar (WTP) konsumen air, dengan menerapkan metode penilaian kontingensi sebagai biaya tambahan pada tagihan air mereka, untuk perbaikan ekosistem danau untuk menjamin keberlanjutan pasokan air tawar dalam jumlah dan kualitas seperti yang diminta oleh utilitas air publik. Survei dilakukan di Kabupaten Semarang dengan melibatkan 116 responden di tiga desa yang menerima layanan air bersih dari Danau Rawapening. Rata-rata WTP adalah sebesar 6.055,54 rupiah (0,433 US \$) per bulan untuk setiap rumah tangga, setara dengan $9,26 \%$ dari rata-rata tagihan air bulanan rumah tangga. Hasil penelitian mengungkapkan bahwa responden yang lebih muda dan berpendidikan, rumah tangga dengan pendapatan lebih tinggi dan anggota yang lebih sedikit, secara rata-rata, bersedia membayar lebih. Penelitian ini juga menunjukkan bahwa kepemilikan sumur air tanah oleh rumah tangga merupakan faktor penghambat untuk berkontribusi dalam memperbaiki ekosistem danau. Hasil dari penelitian ini dapat membantu para pembuat keputusan untuk memahami permintaan publik akan peningkatan ekosistem Danau Rawapening dan untuk merumuskan kebijakan lingkungan yang lebih baik.
\end{abstract}

Kata kunci: Willingness To Pay, Contingent Valuation Method, Danau Rawapening, Air Minum, Semarang

\begin{abstract}
The aim of this study is to estimate willingness to pay (WTP) of water consumers, by applying the contingent valuation method as a surcharge on their water bill, for a given improvement of the ecosystem of Lake Rawapening for ensuring the sustainability of freshwater supply in term quantity and quality as demanded by public water utility. The survey was conducted in Semarang regency involving 116 respondents in three villages that received clean water services from Lake Rawapening. The mean of WTP was estimated to be 6,055.54 rupiahs (0.433 US\$) per month for each household, approximately equivalent to $9.26 \%$ of the average monthly water bill of households. The results revealed that younger educated respondents, households with higher income and with fewer members were, on average, were willing to pay more. This study also demonstrated that households' ownership of shallow water wells was a hindering factor for contributing to improving lake's ecosystem. The results of this study can assist decision-makers to understand the public demand for improved the ecosystem of Lake Rawapening and to formulate better environmental policies.
\end{abstract}

Keywords: Willingness To Pay, Contingent Valuation Method, Lake Rawapening, Drinking Water, Semarang

Citation: Irawan, E. (2019). Contingent Valuation of Lake Rawapening as a Source Raw Drinking Water. Jurnal Ilmu Lingkungan, 17(3), 492499, doi:10.14710/jil.17.3.492-499

\section{Introduction}

Most of the lakes are an important source of raw water reserve for potable water utilities in many countries (Reynaud and Lanzanova, 2017). The extent to which a particular lake can provide raw water in quality and quantity levels as demanded by water utilities is, among other things, highly dependent on the sustainability of its ecosystem. Despite their importance in providing ecosystem services beneficial for human well-being, many lakes in Indonesia are threatened by human activities (Haryani, 2014; Henny and Meutia, 2014; Pawitan and Haryani, 2011; Soeprobowati, 2015). The amount of nutrients loading and soil erosion-sedimentation resulting from human activities continuous to increase from year to year due to the hardly controllable pressure of accelerating population on one side and economic growth on the other. It is now becoming increasingly clear that the changes in lake ecosystems not only undermine their ecological integrity but also alter the supply of ecosystem services resulting in significant consequences for the environment and human wellbeing (Reynaud and Lanzanova, 2017). Eutrophication and sedimentation are currently and in the foreseeable future will remain wicked issues of lake management for developing countries including Indonesia (Haryani, 2014; Henny and Meutia, 2014; Hidayati et al., 2018a; Thornton et al., 2013). In 
responding to this problem, the Indonesian government has recently issued a restoration policy of 15 lakes, one of which is Lake Rawapening.

It has often been argued that a major reason for the failures to preserve lake ecosystems pertains to the lack of readily available data and information on the economic values of ecosystem services of a lake. Failure to quantify the economic value of ecosystem services in commensurate terms with opportunity costs is likely to cause these ecosystem services to be of no value implicitly. This, in large part, contributes to inefficient allocation of the lake resources and in turn degrades the lake ecosystem (Reynaud and Lanzanova, 2017; Zhang and Stenger, 2015).

Exploring the public's willingness-to-pay (WTP) for a lake ecosystem restoration program could help reveal the extent of the quantitative economic value that the public attached to ecosystem services a lake can provide. Moreover, it also could provide information concerning the determining factors of WTP that lead to their concrete action and help policy makers and government officials improve communication and relative environmental protection strategies. Nevertheless, there are a limited number of economic valuation studies of lake ecosystem services that have been conducted in Indonesia (Ginting et al., 2017; Hakim et al., 2011; Putri, 2017; Subanti et al., 2017). Hakim et al. (Hakim et al., 2011) and Subanti et al. (2017) estimated willingness-to-pay (WTP) of visitors for ecotourism of Lake Rawapening, while Putri (2017) and Ginting et al. (2017) estimated WTP of village residents for the preservation of Lake Maninjau ecosystem and wild medicinal plants in the catchment area of Lake Sentarum, respectively. However, none of these previous economic valuation studies conducted in Indonesia estimated the economic value of lake as providers of raw water of freshwater for household or industrial consumption. This article is thus an addition to the scarce literatures on economic value of lakes' ecosystem services. The objective is to estimate the WTP of freshwater consumers for rehabilitation program of Lake Rawapening ecosystem mainly aimed to increase its capacity in providing raw water in quantity and quality as demanded by public water utility of Semarang Regency. However, it is worth mentioning that the impacts of the rehabilitation program will be beyond the improvement of raw water reserves in the lake. Positive impacts that can be expected include the improvement of various ecosystem services of the lake, such as provisioning, regulating, education/cultural and habitat services.

\section{Methods \\ 2.1 Study Area}

This study was conducted in three villages, namely Lemahireng, Kalirejo and Leyangan, which are part of East Ungaran sub-District, Semarang Regency, Central Java Province. Those villages were parts of service area of the municipal water utility (hereafter called PDAM) where its raw water was obtained from
Lake Rawapening. The PDAM served approximately 1200 households in those villages. To serve its customers in the designated areas, the PDAM procured the purified freshwater from PT Sarana Tirta Ungaran, a private company holding a concession for processing raw water from Lake Rawapening.

Lake Rawapening is semi-natural lake situated in Central Java, about $45 \mathrm{~km}$ south of Semarang city (Figure 1). This lake was converted from a marsh to a lake in 1912-16 and enlarged in 1939 by dams on the Tuntang River, the only outlet of the lake. When full, at 463 meters above sea level, the lake covers 2,670 hectares but, in the dry season, may be as small as 620 hectares at 460 meters (PT. Suwanda Karya Mandiri, 2015). The lake provides water for irrigating about 24,000 hectares of rice fields and for generation of 20 Mega Watt of hydroelectric power (Hidayati et al., $2018 b$ ). Since 2003, the government of Semarang regency has begun to use lake water as a source of raw water to meet industrial and household needs of freshwater. Moreover, the use of lake water is to reduce the exploitation of groundwater which currently tends to increase along with rapid growth of factories and housings in Semarang regency.

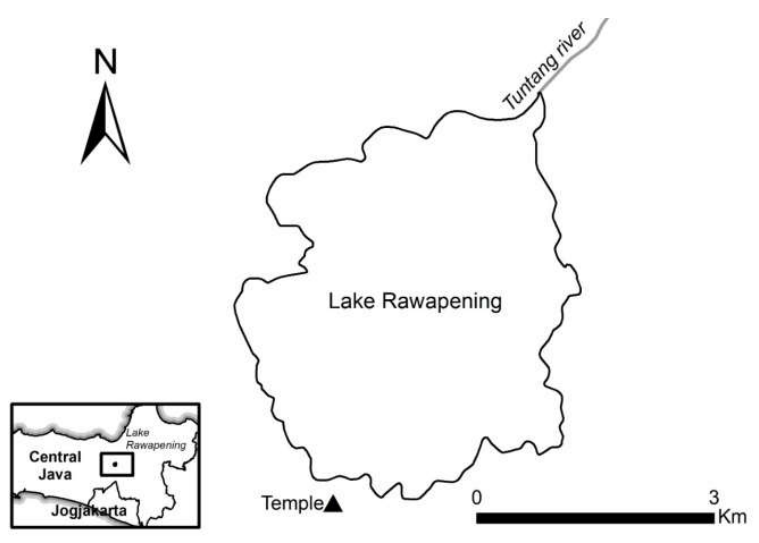

Figure 1. Lake Rawapening

Lake Rawapening is at present facing the problem of eutrophication and sedimentation which threatens its sustainability. Eutrophication has caused the extensive propagation of water hyacinth population. Currently, water hyacinth population has covered almost $70 \%$ of lake's surface and in turn induced a variety of accompanying problems, such as reduced endemic fish species, sedimentation, and reduced lake water quality as well as its amenities. It was estimated that more than 700 tons of eroded soil carried by runoff of 9 sub-watersheds of the lake turn into sediment every year. The average depth of the lake has reduced significantly to an average of 2-3 meters compared to in 2008 its depth could reach an average depth of 3-4 meters. During the last 22 years (19761998) the volume of lakes shrank to 29.34 percent. The lake is likely to turn into the land if there are no immediate restoration efforts. If this happens, drinking water supplies that depend on the 
availability of lake raw water are likely to be disrupted or even stopped altogether.

\subsection{Contigent Valuation Method}

This study employed contingent valuation method (CVM) to estimate WTP of freshwater consumer for rehabilitation program of Lake Rawapening ecosystem aimed at increasing its capacity in providing freshwater reserves for public water utility of Semarang Regency. It is assumed rehabilitation of the lake provide benefits to freshwater consumers, such as the continuity of supply and improvement of freshwater quality, in such a way as to improve their welfare. In addition, the improvements of the lake ecosystem may also provide many other benefits for the wider community, such as increasing fish populations, reducing the risks of flood and drought disasters, sustaining water supply for hydropower and enhancing the natural beauty of the lake. The use of CVM to measure consumers' WTP for non-market environmental goods or services has been widely employed, including the economic valuation of freshwater services provided by lakes or wetlands (e.g. Choi et al., 2017; Hammitt et al., 2001; Loomis et al., 2005).

The elicitation of consumer's WTP using CVM in general can be derived through open-ended or dichotomous choice questions. This study employed a dichotomous choice (DC) approach since it seems more incentive-compatible and imitates real situation in the market than the other three approaches (Haab and McConnell, 2002, p. 18; Loomis et al., 2002). Furthermore, this study applied the single-bound dichotomous choice (SBDC) method. The respondents were requested to accept or reject a suggested bid under a hypothetical market situation.

Empirical estimation of WTP is based on random utility model. Each respondent is assumed to maximize utility $U$ that can be converted to be indirect utility V. According to random utility theory, an individual's utility function (Equation 1) consists of a deterministic component (V) and a random component. The utility function of an individual i on a choice $\mathrm{j}$ can be formulated as

$$
\mathrm{U}_{\mathrm{ij}}(\mathrm{Y}, \mathrm{Q} ; \mathrm{Z})=\mathrm{V}_{\mathrm{ij}}(\mathrm{Y}, \mathrm{Q} ; \mathrm{Z})+\varepsilon_{\mathrm{ij}}
$$

$\mathrm{Y}$ represents income, $\mathrm{Q}$ denotes lake's ecosystem, $\mathrm{Z}$ is a vector of socio-demographic characteristics, and $\varepsilon$ are identically independently distributed (IID) random terms. In line with this reasoning and assuming that utility function is linear in income (Y) and covariates (Z), a probability of an individual respondent is to answer "yes" to a suggested A amount of money for improvement of lake ecosystem from $\mathrm{Q}_{0}$ (status quo) to $\mathrm{Q}_{1}$ (the improved state)

$$
\begin{aligned}
\operatorname{Pr}(\text { yes }) & =\operatorname{Pr}\left(\mathrm{V}_{1}\left(\mathrm{Y}-\mathrm{A}, \mathrm{Q}_{1} ; \mathrm{Z}\right)+\varepsilon_{1} \geq \mathrm{V}_{0}\left(\mathrm{Y}, \mathrm{Q}_{0} ; \mathrm{Z}\right)+\varepsilon_{0}\right) \\
& =\operatorname{Pr}\left(\alpha_{1} \mathrm{Z}+\beta(\mathrm{Y}-\mathrm{A})+\varepsilon_{1} \geq \alpha_{0} \mathrm{Z}+\beta(\mathrm{Y})+\varepsilon_{0}\right) \\
& =\operatorname{Pr}(\varepsilon<\alpha \mathrm{Z}-\beta(\mathrm{A}))
\end{aligned}
$$

where $\alpha=\alpha_{1}-\alpha_{0}$ and $\varepsilon=\varepsilon_{1}-\varepsilon_{0}$. The WTP is represented by $A$ and explained as the compensating surplus measure of a change in welfare; a measure of the total economic value that a consumer pays to improvement of lake ecosystem.

To proceed in estimating the parameters of Equation 2, it is necessary to specify the nature of the random terms $(\varepsilon)$. Given that the error is IID with mean zero, two widely used distributions are the normal and logistic. The cumulative normal distribution is used in probit estimation, while the logistic distribution is used logit estimation. Logit and probit analyses yielded similar marginal effects in most application and the outcomes were similar (Haab and McConnell, 2002). This present study employs a probit regression model to determine respondent's WTP. The empirical of probit model used in this study is specified as follows:

$$
\operatorname{Pr}\left(\text { yes }_{\mathrm{i}}\right)=\Phi\left(\alpha-\beta_{\mathrm{iA}} \cdot A+z_{\mathrm{ij}} \beta_{\mathrm{j}}\right)
$$

where $\Phi$ denotes the cumulative standard normal, $\alpha$ is constant, $\beta_{A}$ is the coefficient of the payment for rehabilitation $(A), \mathbf{z}$ is the vector of explanatory variables influencing response, and $\beta$ is the vector of the corresponding parameters. Subscript $i$ and $j$ indicate the individual respondent and index of

\begin{tabular}{|c|c|c|}
\hline Variable & Definition & Measurement/Unit \\
\hline 1. ypay & $\begin{array}{l}\text { The probability of a } \\
\text { respondent being } \\
\text { willing to pay for } \\
\text { rehabilitation program } \\
\text { of Lake Rawapening }\end{array}$ & $\begin{array}{l}1=\text { Yes WTP; } 0=\text { No } \\
\text { WTP }\end{array}$ \\
\hline 2. bid & $\begin{array}{l}\text { Bid offered to } \\
\text { respondent (Rp.) }\end{array}$ & $\begin{array}{l}1000,2000,3000, \\
4000,5000,6000, \\
7000,8000,9000, \\
10000\end{array}$ \\
\hline 3. age & Age of respondent & Numeric variables \\
\hline 4. gender & Gender of respondent & $1=$ Male $; 0=$ Female \\
\hline 5. educ & $\begin{array}{l}\text { Level of formal } \\
\text { education of respondent }\end{array}$ & $\begin{array}{l}0=\text { Elementary school; } \\
1 \text { = Junior high school; } \\
2 \text { = Senior high school; } \\
3 \text { = Non-degree } \\
\text { diploma; } 4 \text { = Bachelor } \\
\text { degree or higher }\end{array}$ \\
\hline 6. fsize & $\begin{array}{l}\text { Number of family } \\
\text { members living in the } \\
\text { same house as } \\
\text { respondent }\end{array}$ & Numeric variables \\
\hline 7. hhinc & $\begin{array}{l}\text { Monthly family average } \\
\text { income ( } 5 \text { categories; in } \\
\text { millions Rp.) }\end{array}$ & $\begin{array}{l}1=\leq 2 ; 2=>2-\leq 3.5 ; \\
3=>3.5-\leq 5 ; 4=>5- \\
\leq 10 ; 5=>10\end{array}$ \\
\hline 8. bill & $\begin{array}{l}\text { Monthly average water } \\
\text { bill (in thousands Rp.) }\end{array}$ & Numeric variables \\
\hline 9. well & Own shallow water well & $0=$ no, $1=$ yes \\
\hline
\end{tabular}
explanatory variables. The variables used in the probit regression model are shown in Table 1.

Table 1. Description of variables used in the Probit Regression Model

Following Haab and McConell (2002) and Hanemann and Kanninen (2001), mean of WTP is then calculated using the following equation:

$$
\text { Mean WTP }=E\left(\text { WTP } \mid \alpha, \beta, z_{j}\right)=-\frac{\alpha+z_{j} \beta_{j}}{\beta_{A}}
$$


Confidence intervals for the estimated mean WTP are calculated according to the method proposed by Krinsky and Robb (1986).

\subsection{Questionnaire Design and Data Collection}

The questionnaire in the present study was predesigned, tested and refined. The preliminary questionnaire was designed based on previous contingent valuation studies (e.g. Ginting et al., 2017; Loomis et al., 2002) and information gathered from one focus group discussion. Furthermore, the preliminary questionnaire was tested and revised question wording to make it more understandable to the respondents. The final version of questionnaire consisted of three sections: (1) household information, (2) the respondent's knowledge of ecosystem services and current environmental problem of Lake Rawapening, and (3) WTP, including the reasons for being "agree" or "disagree" toward payment being offered. Based on the results obtained in a focus group discussion and pre-test survey, ten different the offer amount of payments were established, ranging from 1,000 rupiahs to 10,000 rupiahs with an increment of 1,000 rupiahs (rupiah is Indonesian currency, 1 USD = 14,000 rupiahs). Each respondent was presented with a single randomly assigned amount of payment. This present study used an extra surcharge of respondents' monthly household water bill as a payment vehicle, with which most respondents are likely to be familiar.

The primary data were collected using personal interview by well-trained interviewers, following the principles of face-to-face that make respondents feel comfortable and at ease (Bateman et al., 2002; Whittington, 2002). The survey was conducted from July to August 2016 involving 120 respondents, which were representatives of household customers of PDAM. The respondents were selected randomly based on information provided by village heads. There were, however, 4 questionnaires that must be dropped because of information inconsistencies provided by the respondents. The survey was administered to heads of households or housewives since either of these persons was the one who well aware of the overall income and expenditures of the household and could make decisions regarding additional expenditures for the household.

\section{Results and Discussions}

\subsection{Socio-demographic characteristics of the respondents}

The socio-demographic characteristics of the respondents are shown in Table 2. The age distribution of the respondents is ranging from 29 to 68 years old with an average age of 49.31 years old. Closer look at the data, it shows that the respondents are predominantly aged over 45 ; this group accounted for over $74 \%$ of the total sample. This reflects the local situation that middle-aged and elderly tends to work in their hometown, while the younger people (below $45)$ tend to work outside.
Table 2. Socio-demographic characteristics of the respondents $(\mathrm{N}=116)$

\begin{tabular}{lrcrr}
\hline Variable & Mean & $\begin{array}{c}\text { Standard } \\
\text { Deviation }\end{array}$ & $\begin{array}{c}\text { Mini- } \\
\text { mum }\end{array}$ & $\begin{array}{r}\text { Maxi- } \\
\text { mum }\end{array}$ \\
\hline 1. age & 49.31 & 8.15 & 29 & 68 \\
2. gender & 0.78 & 0.41 & 0 & 1 \\
3. educ & 2.14 & 1.00 & 0 & 4 \\
4. fsize & 3.84 & 0.94 & 1 & 5 \\
5. hhinc & 2.41 & 1.10 & 1 & 5 \\
6. bill & 65.39 & 47.32 & 10 & 350 \\
7. well & 0.12 & 0.33 & 0 & 1 \\
\hline Source: own survey (processed) & & &
\end{tabular}

Source: own survey (processed)

Most of respondents had completed senior high school degree or higher. Specifically, this group covers more than $83 \%$ of the total sample, while the rest had completed elementary or junior high school degrees. None of the sampled respondents were illiterates or had not finished elementary school.

This study has carefully paid attention to gender factor by striving for gender balance in data collection; thus we attempted to interview equal numbers of males and females. However, the collected data survey turns out that the eventual number of male respondents was larger than the number of females. The male respondents were accounted for $78 \%$ of the total sample reflecting the fact that, in general, men tend to be the representative and are responsible for economic decision-making.

Average household size in the sample was 3.84 persons, which is equivalent to the normal family size in Central Java Province (3.7) (Indonesian Central Agency of Statistics, 2018). Over one-half of the respondents $(51.72 \%)$ had a monthly income below 3.5 million rupiahs (about 250 US\$), whereas 30\% of the respondents received a monthly income of between 3.5 and 5 million rupiahs (about 250 - 357 US\$). It is about $18 \%$ of the total sample that had monthly income more than 5 million rupiahs.

Shallow water wells and PDAM water taps were the two main sources that were widely used by community members at the study site. Some of them used both simultaneously or as a backup when the flow of water from the PDAM pipeline was temporarily constrained. However, the volume of well water usually decreased and was unable to meet household needs during the dry season. At certain spots, dug well water had a low quality and was not suitable for consumption. Among the respondents, there were $12.07 \%$ households relied on both shallow water wells and water taps as a source of freshwater. On average, respondents' household paid monthly water bill of 65.39 thousand rupiahs.

\subsection{Knowledge of Ecosystem Services and \\ Environmental Problems of the Lake}

Respondents were requested to mention some ecosystem services they thought relevant to Lake Rawapening. The results are provided in Table 3. Overall, the answers of respondents consisted of nine types of ecosystem services of Lake Rawapening and could be grouped into three categories, namely provisioning, regulating, and cultural or education. 
The most popular answer was recreation; it accounted for $35.07 \%$ of the overall answers. Second and third places in terms of the popularity of the answers respectively were aquaculture or fisheries and irrigation water. Both were included in the provisioning services group. Other types of ecosystem services were mentioned by less than $10 \%$ respondents. One thing that is interesting to note is that only about $7 \%$ of respondents considered freshwater reserves in lakes as one of the important services provided by Lake Rawapening. This is probably closely related to the fact that the use of lake water as raw water for drinking water only began in 2003. The results revealed that respondents clearly recognize the roles of Lake Rawapening in their lives and others.

Table 3. Respondents' Knowledge of Ecosystem Services of Lake Rawapening

\begin{tabular}{|c|c|c|c|}
\hline & Ecosystem Services & Frequency & Percentage \\
\hline \multirow[t]{7}{*}{1.} & Provisioning services & & \\
\hline & $\begin{array}{l}\text { - Aquaculture and } \\
\text { fisheries }\end{array}$ & 73 & 27.24 \\
\hline & - Freshwater resource & 21 & 7.84 \\
\hline & - Irrigation water & 27 & 10.07 \\
\hline & - Hydroelectric & 24 & 8.96 \\
\hline & $\begin{array}{l}\text { - Peatsoil for organic } \\
\text { fertilizer }\end{array}$ & 4 & 1.49 \\
\hline & $\begin{array}{l}\text { - Materials for artwork } \\
\text { (water hyacinth fiber) }\end{array}$ & 3 & 1.12 \\
\hline \multirow[t]{3}{*}{2.} & Regulating services & & \\
\hline & - Flood control & 19 & 7.09 \\
\hline & $\begin{array}{l}\text { - Habitat for endemic } \\
\text { fishes }\end{array}$ & 3 & 1.12 \\
\hline \multirow[t]{2}{*}{3.} & $\begin{array}{l}\text { Cultural or education } \\
\text { services }\end{array}$ & & \\
\hline & - Recreation & 94 & 35.07 \\
\hline
\end{tabular}

The respondents were furthermore asked to identify the current environmental problems of Lake Rawapening. The results are summarized in Table 4. Explosion of water hyacinth population was mentioned as the most important environmental problem $(60 \%)$. This finding is consistent with the fact that almost $70 \%$ of the lake surface is currently covered by water hyacinth. This is a recurring problem that occurs almost every year even though various remedial efforts, such as mechanical or chemical eradications of water hyacinth and installing concrete barriers (klante) to inhibit their spread, have been done.

Table 4. Respondents' Knowledge of Current Environmental Problems of Lake Rawapening

\begin{tabular}{clcc}
\hline \hline & Environmental problems & Frequency & $\begin{array}{l}\text { Percentag } \\
\mathrm{e}\end{array}$ \\
\hline 1. & Excessive population of & 70 & 60.34 \\
2. & Hater hyacinth & 12 & 10.34 \\
3. & Water pollutions & 17 & 14.66 \\
4. & Massive riparian squatting & 17 & 14.66 \\
\hline Source: own survey (processed) & &
\end{tabular}

Other environmental problems mentioned by respondents were water pollutions, massive riparian squatting and sedimentation. These three environmental problems are closely related to each other. As pollutant-absorbing plants, the presence of water hyacinth in water body of a lake or a river can be considered as an indicator of the problems of water pollution that are triggered by wastes generated by settlements and agricultural activities in riparian areas of the lake. Overall, these results indicate that respondents were aware that the ecosystem of Lake Rawapening was exposed to pollutions and sedimentation that were likely led to degradation.

\subsection{Respondents' attitude towards payment}

In this study, the respondents were also asked the reasons underlying for their choice of whether or not they would pay for the lake rehabilitation program being offered. Table 5 gives the main reasons of the respondents. The most important reason was their concern for the future of freshwater supply to meet household needs. About $12.07 \%$ of the respondents considered the amount of payment offered to be reasonable and the payment itself according to $11.21 \%$ of the respondents was a social obligation that must be borne by every member of the community as beneficiaries of freshwater from the lake. In addition, awareness to contribute in maintaining and restoring the environment was also the reason stated by respondents. This was related to the desire of $8.62 \%$ respondents to pass on a better living environment to the next generations.

Table 5. Reasons for being willing to pay or not being willing to pay

\begin{tabular}{|c|c|c|}
\hline & Reason & Percentage \\
\hline \multicolumn{3}{|c|}{$\begin{array}{l}\text { Respondent's reasons for being willing to } \\
\text { pay }\end{array}$} \\
\hline 1. & $\begin{array}{l}\text { Concerning the future of freshwater } \\
\text { supply }\end{array}$ & 18.97 \\
\hline 2. & Reasonable amount of payment & 12.07 \\
\hline 3. & $\begin{array}{l}\text { Social obligation for making decent } \\
\text { living environment }\end{array}$ & 11.21 \\
\hline 4. & $\begin{array}{l}\text { The desire to pass on a sustainable } \\
\text { lake to the next generations }\end{array}$ & 8.62 \\
\hline 5. & $\begin{array}{l}\text { Willingness to contribute for } \\
\text { environmental protection }\end{array}$ & 4.31 \\
\hline
\end{tabular}

Respondent's reasons for not being willing to pay

1. The amount of payment is unaffordable

2. The program is the responsibility of 6.90 the government

3. I will use other sources of freshwater, such as my own shallow water well

4. My contribution will not be significant compare to the problems of Lake Rawapening

5. I think there are some other community members will pay it

Source: own survey (processed)

For $25.86 \%$ of the respondents, the amount of WTP being offered was unaffordable. This reason is 
most likely related to the burden of routine monthly household expenditures which according to some respondents has been already being large even though these expenditures only covered household basic needs. The payment for lake rehabilitation could reduce budget allocations for other more important household expenses. Therefore, it is not surprising that there were $6.90 \%$ of the respondents who already consider that the problem of preserving the lake was the responsibility of the government. About $2 \%$ of the respondents even implicitly stated to be free-riders of the program.

\subsection{WTP estimates}

Probit model as specified in the preceding section has been employed to identify explanatory variables that influence respondents' WTP for improved Lake Rawapening ecosystem. The variables included in the empirical model were tested for the possibility of the existence of multicollinearity by computing the VIF for continuous variables and contingency coefficients for discrete variables. The results indicated that there was no serious multicollinearity problem among explanatory variables and hence all the hypothesized variables were included in the analysis. The probit regression results are summarized in Table 6.

Table 6. Factors affecting respondents' WTP

\begin{tabular}{lccr}
\hline \multicolumn{1}{c}{ Variable } & Coefficient & $\begin{array}{c}\text { Standard } \\
\text { Error }\end{array}$ & t-value \\
\hline 1. constant & $7.15809^{* * *}$ & 2.18393 & 3.28 \\
2. bid & $-0.00038^{* * *}$ & 0.00009 & -4.18 \\
3. age & $-0.09144^{* * *}$ & 0.03302 & -2.77 \\
4. gender & 0.11037 & 0.45874 & 0.24 \\
5. educ & $0.49346^{* *}$ & 0.22407 & 2.20 \\
6. fsize & $-0.59641^{* *}$ & 0.24737 & -2.41 \\
7. hhinc & $0.39650^{*}$ & 0.23127 & 1.71 \\
8. bill & -0.00063 & 0.00413 & -0.15 \\
9. well & $-1.09407^{*}$ & 0.63651 & -1.72 \\
& & & \\
Log likelihood & $=$ & -36.4205 & \\
Observation & $=$ & 116 & \\
LR chi2(8) & $=$ & 86.73 & \\
Prob $>$ chi ${ }^{2}$ & $=$ & 0.0000 & \\
Pseudo R & $=$ & 0.5435 & \\
Note: Significant at p $\leq 0.1(*), 0.05(* *)$ and $0.01(* * *)$ & \\
Source: own survey(processed) &
\end{tabular}

As shown in Table 5, most of explanatory variables are statistically significant at $10 \%$ or lower. The chi-square result shows that the likelihood ratio statistic is highly significant (P-Value $<0.0001$ ) suggesting that the model has strong explanatory power. The pseudo $\mathrm{R}^{2}$ value indicates how the probit model fits the data set (Greene, 2002; Verbeek, 2000). The pseudo $\mathrm{R}^{2}$ in this model is higher than the $50 \%$ level suggested by Verbeek (2000) as indicating a very good for empirical cross-sectional data.

The estimated coefficient of bid (bid offered to respondent) as expected was negative and statistically significant at the $1 \%$ level. This result indicates that the respondents were less likely to agree to the WTP question if they were presented with a higher bid amount. This result is also consistent with the economic demand theory where the quantity of a product demanded decreases with the increase in the product's price.

The age of respondents (variable age) were found to have a negative sign and statistically significant influence on respondent WTP, implying that the older the respondents the less likely they were to say "yes" to WTP question. This finding is consistent with a recent study conducted by Putri (2017). Likewise, the coefficient of fsize (number of family members) was found negative and statistically significant, reflecting that the respondents with larger number of family members were unlikely to pay for amount of WTP being presented. One possible explanation for this is that a larger family may have more household expenditures for other things. The ownership of shallow water well (variable well) was also found negatively statistically significant, suggesting that respondents having shallow water well were less likely to contribute the improvement of Lake Rawapening's ecosystem. This finding has at least revealed an indication that the respondents substituted shallow water well for piped water of PDAM.

Respondents' education level (variable educ) has been found to have positively significant effect on respondents' WTP. This reflects that the willingness of respondents to say "yes" to WTP question increased with the increase of education level. As expected from the literature, the variable hhinc (monthly household income) had a positive and statistically significant impact on the respondents' WTP. This result suggests that a household with a higher income would have greater WTP. This finding is in agreement with a priori expectations from economic theory, thus serving evidence of the validity of this CVM study and its WTP estimates.

Following the procedure of equation (4), the mean of WTP for Lake Rawapening was estimated to be 6,055.54 rupiahs ( 0.433 US\$) per month for each household, approximately equivalent to $9.26 \%$ of the average monthly water bill of the households. This mean value was derived using the values for the explanatory variables shown in Table 2. The 95 percent confidence interval of WTP was between 5,112.09 and 7,417.99 rupiahs.

Sensitivity analysis was conducted by changing one independent variable, while maintaining the other variables at their mean values. The results are provided in Table 7 . In this case, sensitivity analysis was carried out on two variables namely respondent's water bills (bill) and ownership of shallow water wells (well) to see the extent of the influence of these two variables on changes in the value of WTP. The WTP of households with monthly water bill of 18.07 thousand rupiahs was $6,141.75$ rupiahs per month, whereas the WTP of households with monthly water bill of 112.71 thousand rupiahs was 5,983.60 rupiahs. If the households had shallow water well, the value of their WTP was 3,507.17 rupiahs, while those did not have their WTP was 6,411.15 rupiahs. 
Table 7. Sensitivity analysis

\begin{tabular}{lcc}
\hline \multicolumn{1}{c}{ Variable } & \multicolumn{1}{c}{ Value } & WTP (Rp/Month) \\
\hline 1. bill & $18.07^{*}$ & 6141.75 \\
& $112.71 \#$ & 5983.60 \\
2. well & 0 (min.) & 6411.15 \\
& 1 (max.) & 3507.17 \\
\hline
\end{tabular}

Notes:

* indicates that the value is one standard deviation below the mean value.

\# indicates that the value is one standard deviation above the mean value.

Source: own survey (processed)

The results of sensitivity analysis confirm that the amount of water bill does not have any effects on the value of respondents' WTP, whereas the ownership of shallow water wells has. This implies that the availability of access to clean freshwater sources other than PDAMs might reduce the willingness of the community to participate in the lake ecosystem rehabilitation program. Moreover, if the freshwater sources are accessible at a lower cost than the price of PDAM water, it is likely that the reluctance to contribute to the rehabilitation of the lake will also increase.

\section{Conclusion}

This study employed CVM to estimate WTP for rehabilitation of the ecosystem of Lake Rawapening and to examine factors influencing WTP. The results reveal that there was a demand for improvement for the ecosystem of Lake Rawapening with the main aim of securing the supply raw freshwater for public water utility in Semarang Regency. The mean of WTP of respondents for improvement in the quantity and quality freshwater in Lake Rawapening due to the rehabilitation programs was estimated to be $6,055.54$ rupiahs (0.433 US\$) per month for each household, which is approximately equivalent to $9.26 \%$ of the average monthly water bill of the households. The WTP elicitation was within the respondents' abilities, and the mean WTP estimate was statistically significant. The WTP increases with education of respondents and households' income, as expected, and is negatively related to households' ownership of shallow water wells. Moreover, the age of respondents, family size and the average amount of monthly households' water bill were negatively affected the value of WTP.

On a practical level, the results obtained could have a policy implication, specifically the implementation of payment for environmental services (PES). PES is market-based approach for conservation financing that based on two principles: those who benefit from environmental services should pay for such services and those who provide the services should be compensated (Fauzi and Anna, 2013; Lin and Ueta, 2012; Vatn, 2010). The estimated mean value of WTP derived from this study can be used as a reference point for future price increases for rehabilitation and conservation of freshwater sources and average increase in the current water bill of around 9.26\% for the residents in Semarang Regency.

Although this study has demonstrated reasonable results, it is recommended to recognize that the results are based on a relatively small sample. Nevertheless, the results of this study can still be applied in other places that have similar ecological and socioeconomic characteristics to the research location. In addition, the average value of WTP is based on the CV method which depends on the hypothetical situation rather than the actual one. It is highly recommended to conduct a validating study to test whether the hypothetical WTP differs from the actual WTP. Finally, more studies with alternative methods need to be carried out to confirm the findings of this study as inputs for better policies making.

\section{REFERENCES}

Bateman, I.J., Carson, R.T., Day, B., Hanemann, W.M., Hanley, N., Hett, T., Lee, M.J., Loomes, G., Mourato, S., Özdemiroglu, E., Pearce, D.W., Sugden, R., Swanson, J., Hanemann, M., Hanley, N., Hett, T., Jones-Lee, M., Loomes, G., 2002. Economic Valuation with Stated Preference Techniques: A Manual, Economic Valuation with Stated Preference Techniques. Edward Elgar, Cheltenham, UK.

Choi, I.C., Kim, H.N., Shin, H.J., Tenhunen, J., Nguyen, T.T., 2017. Economic valuation of the aquatic biodiversity conservation in South Korea: Correcting for the endogeneity bias in contingent valuation. Sustainability (Switzerland) 9.

Fauzi, A., Anna, Z., 2013. The complexity of the institution of payment for environmental services: A case study of two Indonesian PES schemes. Ecosystem Services 6, 54-63.

Ginting, T., Ismail, A., Simangunsong, B., 2017. Economic Value of Medicinal Plants in Danau Sentarum National Park, West Kalimantan. Jurnal Ekonomi dan Pembangunan Indonesia 18, 22-34.

Greene, W.H., 2002. Econometric analysis, 5th ed, Journal of the American Statistical Association. Prentice Hall, Upper Saddle River, NJ, NJ.

Haab, T.C., McConnell, K.E., 2002. Valuing Environmental and Natural Resources: The Econometrics of Non-Market Valuation, New Horizons in Environmental Economics. Edward Elgar, Cheltenham, UK.

Hakim, A.R., Subanti, S., Tambunan, M., 2011. Economic Valuation of Nature-Based Tourism Object in Rawapening, Indonesia: An Application of Travel Cost and Contingent Valuation Method. Journal of Sustainable Development 4, 91-101.

Hammitt, J.K., Liu, J.-T., Liu, J.-L., 2001. Contingent valuation of a Taiwanese wetland. Environment and Development Economics 6, 259-268. 
Hanemann, M., Kanninen, B., 2001. The Statistical Analysis of Discrete-Response CV Data. In: Bateman, I.J., Willis, K.G., Kanninen, B.J. (Eds.), Valuing Environmental Preferences. Oxford University Press, Oxford, UK, pp. 302-441.

Haryani, G.S., 2014. Kondisi Danau di Indonesia dan Strategi Pengelolaannya. In: Chrismadha, T., Fakhrudin, M., Nofdianto, Said, D.S., Sulawesty, F. (Eds.), Perkembangan Limnologi Dalam Mendukung Pembangunan Berkelanjutan Di Indonesia: Tantangan Dan Harapan. Masyarakat Limnologi Indonesia, Bogor, Indonesia, pp. 1-19.

Henny, C., Meutia, A.A., 2014. Urban Lakes in Megacity Jakarta: Risk and Management Plan for Future Sustainability. Procedia Environmental Sciences 20, 737-746.

Hidayati, N., Soeprobowati, T.R., Helmi, M., 2018a. The evaluation of water hyacinth (Eichhornia crassiper) control program in Rawapening Lake, Central Java Indonesia. IOP Conference Series: Earth and Environmental Science 142, 0-5.

Hidayati, N., Soeprobowati, T.R., Helmi, M., 2018b. The evaluation of water hyacinth (Eichhornia crassiper) control program in Rawapening Lake, Central Java Indonesia. In: IOP Conference Series: Earth and Environmental Science.

Indonesian Central Agency of Statistics, 2018. Statistical Yearbook of Indonesia 2018. Indonesian Central Agency of Statistics, Jakarta, Indonesia.

Krinsky, I., Robb, a L., 1986. On Approximating the Statistical Properties of Elasticities. Review of Economics and Statistics 68, 715-719.

Lin, H., Ueta, K., 2012. Lake watershed management: Services, monitoring, funding and governance. Lakes and Reservoirs: Research and Management 17, 207-223.

Loomis, J., Kent, P., Strange, L., Fausch, K., Covich, A., 2002. Measuring the total economic value of restoring ecosystem services in an impaired river basin: results from a contingent valuation survey. Ecological Economics 33, 103-117.

Loomis, J., Smith, A., Huszar, P., 2005. Estimating the economic benefits of maintaining residential lake levels at an irrigation reservoir: A contingent valuation study. Water Resources
Research 41,1-9.

Pawitan, H., Haryani, G.S., 2011. Water resources, sustainability and societal livelihoods in Indonesia. Ecohydrology and Hydrobiology 11, 231-243.

PT. Suwanda Karya Mandiri, 2015. Studi Pengukuran, Sedimentasi dan Kualitas Air Waduk Rawa Pening. Semarang, Indonesia.

Putri, I.A.P., 2017. Socio-economic Awareness on Protecting Lake Maninjau Using Willingness to Pay. Jurnal Sosial Ekonomi Pekerjaan Umum 9, 28-37.

Reynaud, A., Lanzanova, D., 2017. A Global MetaAnalysis of the Value of Ecosystem Services Provided by Lakes. Ecological Economics 137, 184-194.

Soeprobowati, T.R., 2015. Integrated Lake Basin Management for Save Indonesian Lake Movement. Procedia Environmental Sciences 23, 368-374.

Subanti, S., Hakim, I.M., Daerobi, A., Nasir, M.S., Hakim, A.R., 2017. Determinant of Willingness to Pay and Economic Value for Ecotourism Object Using Contingent Valuation Method : The Case of Rawapening, Semarang Regency, Central Java, Indonesia 28, 250-252.

Thornton, J.A., Harding, W.R., Dent, M., Hart, R.C., Lin, H., Rast, C.L., Rast, W., Ryding, S.O., Slawski, T.M., 2013. Eutrophication as a "wicked" problem. Lakes and Reservoirs: Research and Management 18, 298-316.

Vatn, A., 2010. An institutional analysis of payments for environmental services. Ecological Economics 69, 1245-1252.

Verbeek, M., 2000. A Guide to Modern Econometrics. John Wiley and Sons, Sussex, United Kingdom.

Whittington, D., 2002. Improving the performance of contingent valuation studies in developing countries. Environmental and Resource Economics 22, 323-367.

Zhang, D., Stenger, A., 2015. Value and valuation of forest ecosystem services. Journal of Environmental Economics and Policy 4, 129140. 